\title{
Climate variations in a high altitude Alpine basin and their effects on a glacial environment (Italian Western Alps)
}

\author{
ELISA GIACCONE, NICOLA COLOMBO and FIORELLA ACQUAOTTA \\ Dipartimento di Scienze della Terra, Università degli Studi di Torino, via Valperga Caluso 35, 10125 Torino, Italy
}

LUCA PARO

Dipartimento Geologia e Dissesto, Arpa Piemonte, via Pio VII 9, 10135 Torino, Italy

\begin{abstract}
SIMONA FRATIANNI
Dipartimento di Scienze della Terra, Università degli Studi di Torino, via Valperga Caluso 35, 10125 Torino, Italy; Centro di Ricerca sui Rischi Naturali in Ambiente Montano e Collinare (NatRisk), via Leonardo da Vinci 44, 10095 Grugliasco, Italy

Corresponding author: simona.fratianni@unito.it
\end{abstract}

Received June 4, 2014; accepted February 6, 2015

\section{RESUMEN}

El principal objetivo de este estudio es evaluar la variación de los parámetros climáticos (temperatura, lluvia y nieve) medidos en dos estaciones meteorológicas (Formazza y Sabbione) que nunca antes se habían analizado, ubicadas en un ambiente glaciar (la cuenca del Sabbione en los Alpes occidentales italianos). El estudio se centra en la evolución climática de la cuenca alpina durante los últimos 60 años (1950-2012): el cambio climático ha causado una declinación glaciar pronunciada cuyo origen es el aumento de la ablación debido principalmente al incremento de la temperatura del aire y la reducción de la alimentación, a su vez ocasionada por la disminución de nieve fresca. La prueba de correlación cruzada muestra que la temperatura influye sobre la dinámica de la retracción glaciar más que la precipitación de la nieve. Se han identificado formas periglaciares y ligadas al permafrost (p. ej., suelos estructurados y glaciares de roca) en depósitos de glaciares provenientes de la Pequeña Edad de Hielo (PEH), lo cual evidencia la transición de un ambiente glaciar/ proglaciar a un ambiente periglaciar aún en curso. Además, para identificar mejor el dominio periglaciar de la cuenca, se ha elaborado un mapa de la temperatura media anual del aire a partir de los análisis climáticos.

\begin{abstract}
The main objective of this study is to evaluate the variations of climatic parameters (temperature, rain and snow) measured by two weather stations (Formazza and Sabbione) that have never been analyzed before, located in a high glacial catchment (the Sabbione basin in the Italian Western Alps). The study highlights the climatic evolution of the Alpine basin during the last 60 years (1950-2012): climate change has caused a pronounced glacial decline originated by ablation augmentation, due mainly to increasing air temperatures and to reduced alimentation caused by a fresh snow decrease. The cross-correlation test shows that temperatures affect the glacial retreat dynamics more than snowfall. Periglacial and permafrost landforms (e.g., patterned grounds, rock glaciers) have been identified within the Little Ice Age (LIA) glacial deposits, which indicate the ongoing transition from glacial/proglacial to periglacial environments. Furthermore, in order to better identify the periglacial domain in the basin, a map of mean annual air temperature (MAAT) was produced based on climatic analysis.
\end{abstract}

Keywords: Climate change, glacial decline, permafrost, Italian Western Alps. 


\section{Introduction}

In the last years, several studies have demonstrated the existence of accelerated climate modifications that have affected the whole Earth, in particular the most vulnerable ecosystems such as mountainous regions. In the last 100 years (1906-2005), the global mean air temperature has increased $0.74 \pm$ $0.18^{\circ} \mathrm{C}$, while in the Alps the increase in temperature is almost the double (Auer et al., 2007; IPCC, 2007). Minimum air temperatures in the Alps have increased more than maximum air temperatures, which have shown a limited rise (Böhm et al., 2001; Beniston, 2005; EEA, 2009). Moreover, there have been changes in precipitation amounts, especially in fresh snow, although they are not geographically homogeneous due to the heterogeneous morphology of the alpine region and the high complexity of alpine climate (Fratianni et al., 2009; Terzago et al., 2010, 2012; Acquaotta and Fratianni, 2013). In particular, in the Western Italian Alps a decrease in the fresh snow amount and snow cover permanence has been observed, which is closely related to the temperature rising as highlighted by the studies of Terzago et al. (2013), Acquaotta et al. (2014) and Fratianni et al. (2015).

At high altitudes, climatic variations interact with glacial processes and influence the dynamics of alpine ecosystems. Mountain glaciers are the major fresh water source for people living in or nearby the adjacent lowlands of mountain ranges (Barnett et al., 2005). The observed worldwide glacier retreat is thus an important concern for the availability of fresh water. For example, in 1850 the total area covered by Alpine glaciers was about $4500 \mathrm{~km}^{2}$, while in 2000 it reduced to about $2270 \mathrm{~km}^{2}$ (around-50\%) (Cat Berro et al., 2008). Italian alpine glaciers have also suffered a general retreat since the end of the Little Ice Age (LIA) and this regression has been accelerating in recent years due to the effects of climate warming. This trend has also been observed in the study area (Sabbione basin), where glaciers have been retreating since the second half of the 19th century.

The regression of glaciers allows the formation of periglacial environmental conditions in deglaciated areas with a range of cold/non-glacial processes (French, 2007). The periglacial environment is characterized by the presence of frost action and cryotic morphogenetic processes (Tricart, 1968; Péwé, 1969), and of permafrost, defined as "soil and/or rock that has remained below $0{ }^{\circ} \mathrm{C}$ for more than two consecutive years" (Brown and Péwé, 1973).

In the present work, the data extracted from two high altitude meteorological stations (named "Formazza" and "Sabbione") located in the Sabbione basin (Ossola Valley, North Piedmont, Italy) were analyzed for the first time in order to: (1) characterize the climate of the study area; (2) identify the trends of the main climatic parameters; (3) verify the existence of climatic conditions for the development of cryotic processes, using also the data recorded in other stations situated in the Ossola Valley (Agaro, Alpe Devero, Toggia and Vannino), and (4) investigate the morpho-climatic evolution of the basin, considering in particular the glacial/ proglacial/periglacial transition. In this area several cryotic geomorphological occurrences have been highlighted during field surveys within deglaciated areas since the 1950s (Colombo et al., 2013). Moreover, other meteorological stations (Canevarolo et al., 2011) close to the study area, have been considered to estimate the basin areas included into the periglacial domain through mean annual air temperature (MAAT).

Indeed, according to the empirical definition proposed by French (2007), the MAAT $<3{ }^{\circ} \mathrm{C}$ is considered for the definition of periglacial domain. Guglielmin (2004) divides this domain, called "sensu lato" periglacial environment, in: (1) "sensu stricto" periglacial environment (MAAT between +3 and $0{ }^{\circ} \mathrm{C}$ ), and (2) permafrost environment (MAAT $<0{ }^{\circ} \mathrm{C}$ ). Rainfall is less than $2000 \mathrm{~mm} /$ year (André, 2003; Boelhouwers, 2003).

Changes in glaciers are related to climatic variables through their energy and mass balance. Negative changes in the mass balance of a glacier result either from increased ablation or decreased accumulation, which are mainly determined by precipitation and air temperature (Leonelli et al., 2011; Senese et al., 2012). Thus, to understand the effects of climate evolution on glacial dynamics, two climatic parameters (summer air temperature and fresh snow) have been correlated with the frontal glacier regression of the northern Sabbione glacier for the time span 1978-2005.

\section{Study area}

The Sabbione basin is located in the Formazza Valley (Ossola Valley, Lepontine Alps, Italy, $46^{\circ} 41^{\prime} \mathrm{N}$, $8^{\circ} 34^{\prime} \mathrm{E}$ ), forming the upper basin of the Toce river and the Swiss border (Fig. 1). The major peaks of the 


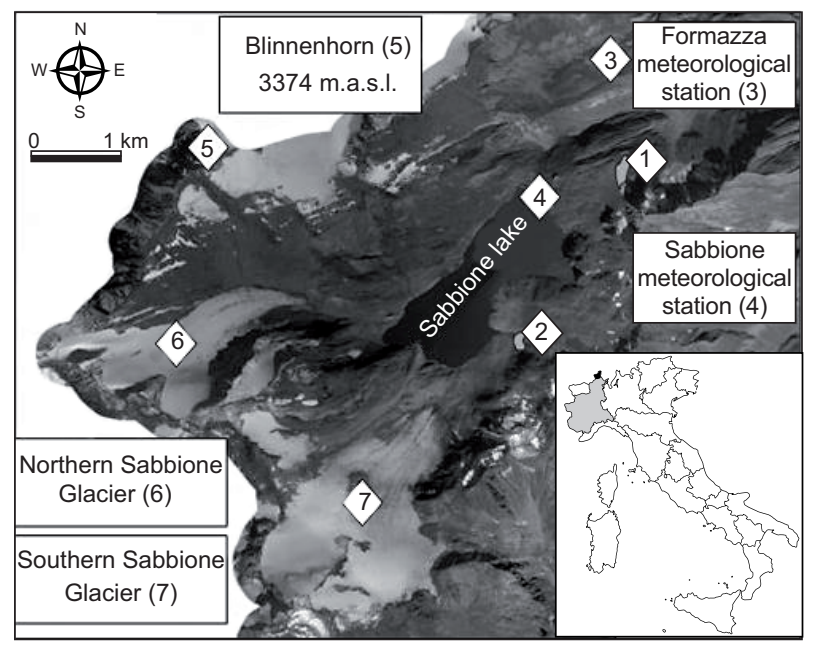

Fig. 1. Digital orthoimage of the study area: 1 and 2, rock glaciers; 3, Formazza meteorological station; 4, Sabbione meteorological station, 5, Blinnenhorn peak; 6, Northern Sabbione Glacier; 7, Southern Sabbione Glacier (details in the text). Source: Ministero dell'Ambiente e della Tutela del Territorio e del Mare - Geoportale nazionale, 2006 (wms service available at: http://wms.pcn.minambiente. it/ogc?map=/ms_ogc/WMS_v1.3/raster/ortofoto_colore_06.map).

basin are: Blinnenhorn (3374 masl; Fig. 1[5]), Corno di Ban (3027 masl), Gemelli di Ban (2946 masl), Punta d'Arbola (3235 masl) and Hohsandhorn (3182 masl).

A storage lake of $1.23 \mathrm{~km}^{2}$ (about 26 million $\mathrm{m}^{3}$ ) is located in the basin, which gathers the ablation waters of the glaciers situated within the area; the main glaciers are the northern Sabbione glacier (Fig. 1 [6]) and the southern Sabbione glacier(Fig. 1 [7]) (about $3.8 \mathrm{~km}^{2}$ of total covered area in 2007), the Blinnenhorn glacier and the Gemelli di Ban glacier. The major glaciers lie in the northwestern sector of the basin, between Punta d'Arbola and Blinnenhorn. Glaciological campaigns, literature data review and field surveys have allowed to quantify the regression of the northern and southern Sabbione glaciers. These glacial fronts have retreated approximately $2 \mathrm{~km}$ in the period 1885-2011, with the second one showing a more pronounced reduction due to the effect of calving at the glacier front, after the creation of the artificial lake in the 1950s (Mazza and Mercalli, 1992; Mazza, 1993; Mazza, 2007).

A large amount of glacial deposits $\left(3.2 \mathrm{~km}^{2}\right)$ outcropped after the glaciers retirement. Periglacial landforms have been identified in these deposits
(Colombo et al., 2013), deriving from freeze-thaw cycles (e.g., patterned ground and gelifluction lobes) and permafrost processes (rock glaciers and protalus rampart) (Barsch, 1996; Baroni et al., 2004). In particular, two active rock glaciers are recognized within the basin: the biggest is a talus rock glacier situated within a deglaciated area, probably since the end of the last glacial maximum (LGM) (Fig. 1 [1]); here a bottom temperature of the snow cover (BTS) (Haeberli, 1973; Guglielmin and Tellini, 1994) measurement campaign was performed by the Agenzia Regionale per la Protezione Ambientale (Regional Agency for Environmental Protection, ARPA) of Piedmont in the late 2011 winter, showing the likely presence of permafrost. The other one (Fig. 1 [2]) is a debris rock glacier located in the lateral moraine of the southern Sabbione glacier, retreated since the 1950 s as shown in aerial photos.

So, the Sabbione basin is an interesting area of study since it is characterized by various typologies of environment in evolution (glacial and periglacial), influenced also by an artificial lake that has conditioned in particular the glacial reduction.

\section{Data and methods}

The data sets recorded in the meteorological stations Formazza and Sabbione cover the periods 1988-2012 and 1950-2012, respectively. Formazza is an automatic weather station located in the Pian dei Camosci area (2453 masl) and it belongs to the weather regional network managed by ARPA Piemonte. Sabbione is a manned weather station situated in the dam area (2470 masl) owned by the Enel power company, which manages also the hydroelectric plant; it is the nearest station to the glaciers (about $2.4 \mathrm{~km}$ in 2010), which allows having direct measurements of meteorological variables with long continuity.

The elimination of months with daily data lower than $80 \%$ (Sneyers, 1990) and a quality control (QC) with the RClimDex software (Zhang and Yang, 2007) were performed before the analysis (Acquaotta and Fratianni, 2014; Acquaotta et al., 2015). The QC allowed to identify all missing values, unreasonable values (such as daily precipitation amounts lower than zero and maximum temperatures lower than minimum temperatures) and outliers in daily values. At the same time, a historical research on the meteorological stations was carried out; breaks (called metadata) in the series homogeneity, either 
due to changes of location or of instrument, were determined. We consulted the hydrological annals (archives of the Hydrographic and Mareographic National Service), which report yearly the geographic coordinates (latitude, longitude and elevation) and the instrument type for each station. Furthermore, we inspected the original records on which potential breaks and changes of location or instrumentation have been marked. Then, to evaluate the degree of homogenization of the series we compared our data with the neighboring stations (Agaro, Alpe Devero, Toggia and Vannino) (Peterson et al., 1998; Wijngaard et al., 2003; Acquaotta et al., 2009; Venema et al., 2012).

For the Sabbione station metadata was not present. The station was not moved, nor the neighboring environment was modified. The comparison with the neighboring stations did not highlight discontinuities in the series, so the data can be considered homogeneous. Formazza station data was not homogenized either, because the series has not metadata and the comparison with other neighboring meteorological stations has shown good results.

The values from both stations were aggregated on monthly, seasonal and annual basis obtaining an annual average for the main climatic parameters (temperature, precipitation, snow and wind [the last one only for the Formazza station, which is equipped with anemometer]).

Trends were calculated only for the longest time dataset of the Sabbione station; the parameters analyzed were maximum and minimum air temperatures, maximum and minimum summer air temperatures, cumulated precipitation, number of rainy days, cumulated fresh snow, snow depth, number of snowy days, period of snow cover absence and number of freezethaw daily cycles (days with maximum air tempera-

Table I. Climatic indices used in this work.

\begin{tabular}{ll}
\hline CDD & $\begin{array}{l}\text { Consecutive dry days, maximum number } \\
\text { of consecutive dry days (Rday }<1 \mathrm{~mm} \text { ). }\end{array}$ \\
\hline CWD & $\begin{array}{l}\text { Consecutive wet days, maximum number of } \\
\text { consecutive wet days (Rday } \geq 1 \mathrm{~mm} \text { ). }\end{array}$ \\
\hline FD0 & $\begin{array}{l}\text { Frost days, number of days with frost (daily } \\
\left.\text { Tmin }<0{ }^{\circ} \mathrm{C}\right) .\end{array}$ \\
\hline ID0 & $\begin{array}{l}\text { Ice days, number of days with ice (daily } \\
\left.\text { Tmax }<0{ }^{\circ} \mathrm{C}\right) .\end{array}$ \\
\hline
\end{tabular}

ture $>0{ }^{\circ} \mathrm{C}$ and minimum air temperature $\leq 0{ }^{\circ} \mathrm{C}$ ). To evaluate variations in extreme events the climatic indices and related trends were also calculated. These indices (Table I) were selected from the Expert Team on Climate Change Detection, Monitoring and Indices (ETCCDMI), which has been coordinating an international effort to develop, calculate and analyze a suite of climate extremes indices (Klein Tank et al., 2009). The non-parametric test of Mann-Kendall was used to verify the statistical significance, assuming a 95\% probability level (Sneyers, 1990, 1992).

The standardized anomaly index (SAI) (Hereford et al., 2002; Nigrelli and Collimedaglia, 2012) was also calculated for fresh snow, snow depth, and annual and summer (June-September) temperatures at the Sabbione station for the reference period (1971-2000), in order to identify climatic anomalies. The SAI is calculated as a difference between a datum and the sample mean divided by the standard deviation:

\section{$S A I=(x-\mu) / \sigma$}

where $x$ is the datum, $\mu$ is the mean and $\sigma$ is the standard deviation. Furthermore, the 5-yr moving average was calculated.

As a first-order approximation, the long-term MAAT can be used to delineate mountain regions and altitudinal belts with permafrost occurrences (Haeberli et al., 2010). In the present work, statistical analyses combined with a literature review of climate data series allowed to evaluate the relationships between climatic parameters and altitude within the basin. A MAAT map was realized for the reference period (1971-2000) in order to estimate the distribution of areas with potential presence of cryotic processes and permafrost, by using air temperature data recorded at Sabbione (2470 masl) and other stations situated in the Ossola Valley, such as Agaro (1600 masl), Alpe Devero (1634 masl), Toggia (2165 masl) and Vannino (2177 masl) (Canevarolo et al., 2011). The vertical temperature lapse rate was calculated using the data extracted from the five weather stations, and the statistical significance of correlation obtained from ordinary linear least square regression analysis was verified by using the non-parametric test of Mann-Kendall.

Finally, in order to understand how climatic conditions affect the glacial retreat dynamics, the annual 
and cumulated frontal regression of northern Sabbione glacier was analyzed. The data were acquired for the time-lapse 1978-2005 (which is the most complete acquisition period for the investigated glacier) using the campaign results of the Comitato Glaciologico Italiano (Italian Glaciological Committee, CGI). Then, the cross-correlation test was applied (Chen, 1982; Childers, 1982; Kearey and Brooks, 1991; Telford et al., 1992; Belloni et al., 2001). Summer temperatures (June-September) that influence the snow permanence on the glaciers, as well as the glaciers mass balance, annual fresh snow (from September to August of the following year, to compare with the glacier's data collected every September), and glacier cumulated regression, were used as input data.

\section{Results and discussion}

The annual average values of the main climatic parameters are shown below.

With the preliminary control of the Formazza series for the time-frame November 1988-June 2012, 19 of 284 months $(6.7 \%)$ with daily data lower than $80 \%$, corresponding to a maximum of six non-consecutive days in a month, were deleted. The analysis of air temperature shows an annual air temperature of $-0.2{ }^{\circ} \mathrm{C}$; the coldest month is January $\left(-6.9^{\circ} \mathrm{C}\right)$ and the warmest is August $\left(7.5^{\circ} \mathrm{C}\right)$. The most extreme recorded values are: $-28.3{ }^{\circ} \mathrm{C}$ (February 7, 1991) for the minimum air temperature and $19.4{ }^{\circ} \mathrm{C}$ (September 8,1998 ) for the maximum air temperature. The number of freeze-thaw cycles is 123 and these are mainly concentrated in spring and autumn.

The rainfall is $995.1 \mathrm{~mm}$, with a maximum of $1311.8 \mathrm{~mm}$ in 1999. The precipitation is concentrated in warmer months, especially June and September. The number of rainy days is 112 , with a maximum of 138 days in 2006 . The pluviometric regime cor- responds to the continental type with a principal maximum in summer, secondary maximum in autumn, principal minimum in winter, and secondary minimum in spring.

The fresh snow is $696.2 \mathrm{~cm}$. Snowfall is more abundant in November, with an average of $143 \mathrm{~cm}$. The number of snowy days is 60 and the maximum number of snowy days occurs in November (10). The snow depth is $97.1 \mathrm{~cm}$ and the extreme value was recorded on April 29, 2009 when $457 \mathrm{~cm}$ of snow were measured. The nivometric regime is unimodal with a spring maximum.

The wind speed is $2.5 \mathrm{~m} \mathrm{~s}^{-1}$ with an absolute maximum gust of $36.1 \mathrm{~m} \mathrm{~s}^{-1}$ registered on March 29, 1995. The anemometric regime is bimodal with two prevailing directions: North-East, typical of spring and summer, and South-West, predominant during autumn and winter.

The data acquisition time-frame (December 1950-June 2012) of the Sabbione station shows that temperature is $-0.9^{\circ} \mathrm{C}$. The coldest month is January $\left(-8.0^{\circ} \mathrm{C}\right)$ and the warmest is August $\left(7.2^{\circ} \mathrm{C}\right)$. The measured extreme values are: $-32{ }^{\circ} \mathrm{C}$ (January 6 , 1985) for the minimum air temperature and $21{ }^{\circ} \mathrm{C}$ (August 13, 2003) for the maximum air temperature. The number of freeze-thaw cycles is 116 and they occur mainly during spring and autumn.

The precipitation is $1034.8 \mathrm{~mm}$, with a maximum of $1601 \mathrm{~mm}$ recorded in 1977 . The rainfall is concentrated in warmer months, especially June and August. The annual average number of rainy days is 127, with a maximum of 144 days recorded in 1972. The pluviometric regime is continental.

The fresh snow is $741.3 \mathrm{~cm}$. Snowfall is more abundant in November, with an average value of $123 \mathrm{~cm}$. The number of snowy days is 64 and the maximum number of snowy days occurs in November (10). The snow depth is $128.3 \mathrm{~cm}$, with a

Table II. Sabbione station trends (1951-2011).

\begin{tabular}{lcl}
\hline Climatic parameters & \multicolumn{1}{c}{ Trend } & Statistical significance $(p$-value $<0.05)$ \\
\hline Maximum temperature & $0.03 \pm 0.01^{\circ} \mathrm{C} /$ year & Significantly \\
Minimum temperature & $0.04 \pm 0.01^{\circ} \mathrm{C} /$ year & Significantly \\
Rainfall & $1.15 \pm 1.9 \mathrm{~mm} /$ year & Non significantly \\
Rainy days & $-0.25 \pm 0.11$ days $/$ year & Non significantly \\
Fresh snow (HN) & $-3.17 \pm 1.35 \mathrm{~cm} /$ year & Significantly \\
Snow depth (HS) & $-0.82 \pm 0.27 \mathrm{~cm} /$ year & Significantly \\
Snowy days & $-0.06 \pm 0.09$ days $/$ year & Non significantly \\
Snow cover absence & $0.08 \pm 0.1$ days/year & Non significantly \\
\hline
\end{tabular}


maximum value of $700 \mathrm{~cm}$ observed on February 15,1951 . The nivometric regime is unimodal with a spring maximum. The snow cover absence is of 102 days, concentrated in the months of July, August, September and October.

The trends of the Sabbione station (1951-2011) are shown in Table II.

After an increase in the 1950s-1960s and a decrease during the 1970s-1980s, maximum and minimum temperatures have risen constantly. The snow (HN and HS) shows an opposite trend: it decreased in the 1950s-1960s, increased during the 1970s-1980s and decreased again in the following years (Fig. 2a, b).

For the climatic index, consecutive dry days and consecutive wet days have a non-significant positive trend. Frost days show a statistically significant decrease of $-0.68 \pm 0.13$ days/year (Fig. $2 \mathrm{c}$ ) and ice days present a statistically significant decrease of $0.49 \pm 0.17$ days/year (Fig. $2 d$ ). These results indicate a general rise in temperature that limits the frost and ice periods.

The fresh snow and snow depth SAIs are generally included between +1 and -1 . From 1975 to 1986, the SAI was between +1 and +2 , indicating a positive moderate anomaly; during the last 15 years the SAI has been often included between -1 and -2 , indicating a negative moderate anomaly (Fig. 3).

The annual temperatures SAI shows negative values at the start of the 1950s, in the 1960s and in the 1980s. The positive values are concentrated at the beginning of the 1970s and from the late 1980s to the end of the time span analyzed, evidencing a recent warming (Fig. 4a).
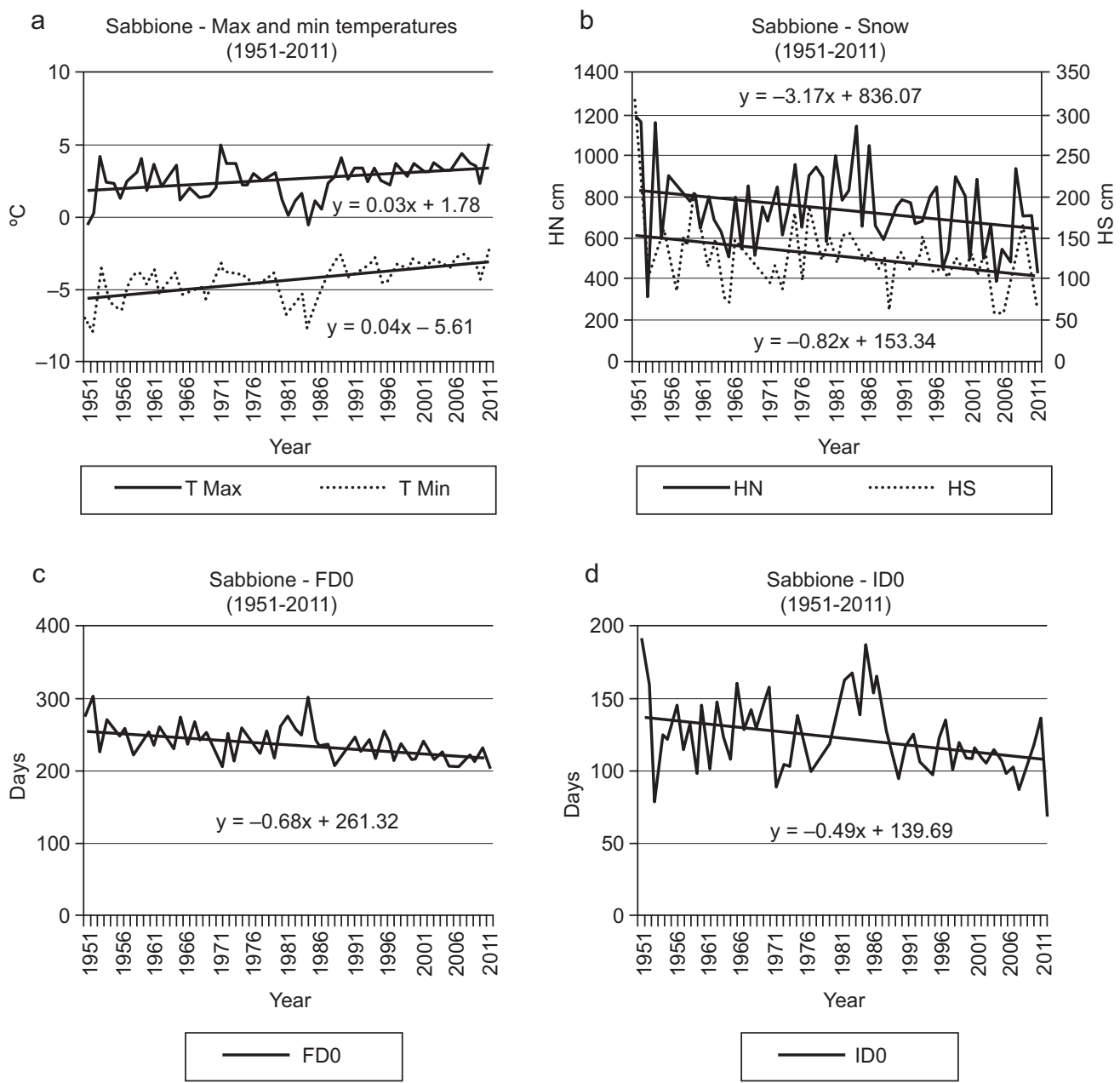

Fig. 2. Results of the Sabbione station analysis: (a) Temperature trends; (b) Snow trends; (c) Frost days trend; (d) Ice days trend. HN: fresh snow; HS: snow depth. 


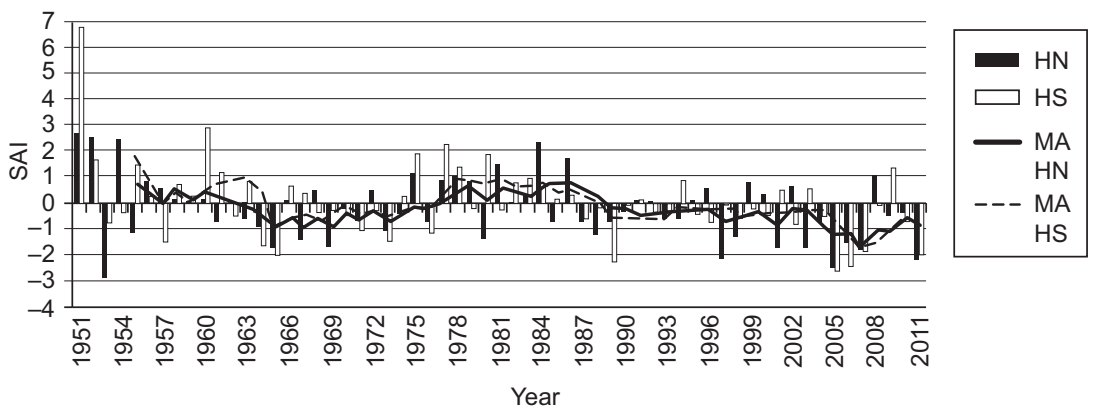

Fig. 3. SAI of annual snow depth (HS) and fresh snow (HN) series for Sabbione (1951-2011) with a 5-yr moving average (MA). The continuous line indicates MA for HN, and the dotted line indicates MA for HS.
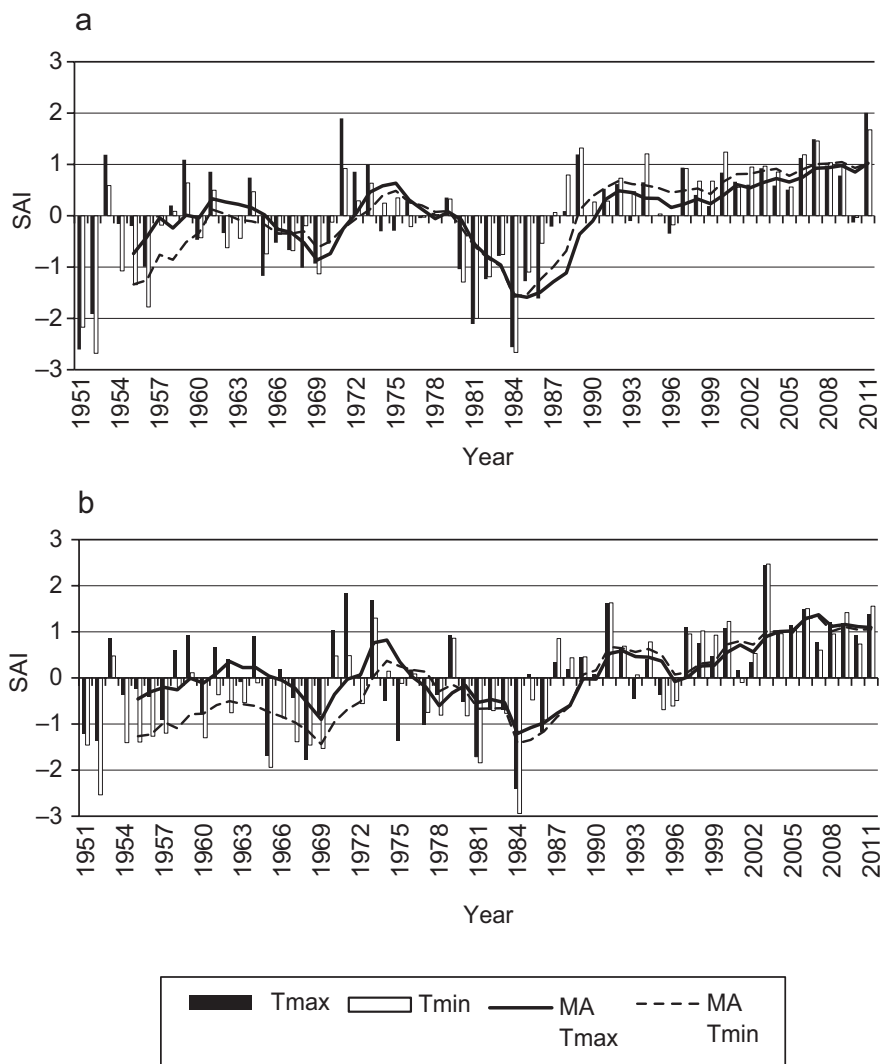

Fig. 4. SAI of annual (a) and summer (b) temperatures series for Sabbione (1951-2011) with a 5-yr moving average (MA). The continuous line indicates MA for Tmax, and the dotted line denotes MA for Tmin.

The summer temperatures SAI follow the previous indices but they are more marked. In particular, 1984 is the coldest year with a SAI of -2.5 , and 2003 is the warmest year with a SAI of +2.3 (Fig. $4 b$ ).

The average annual values of the main climatic parameters were associated with those extracted from other Ossola weather stations, analyzed in previous studies: Agaro, Alpe Devero, Toggia, and Vannino (Canevarolo et al., 2011), situated within $15 \mathrm{~km}$ of the Sabbione station (Table III). The elevation gradient for air temperature, precipitation, fresh snow and snow depth was calculated for the time-frame 19712000 applying the statistical test of Mann-Kendall to verify the statistical significance. 
Table III. Average annual values of the main climatic parameters for Ossola Valley in the 30 -yr period from 1971 to 2000.

\begin{tabular}{cccccc}
\hline Station & Agaro & Alpe Devero & Toggia & Vannino & Sabbione \\
\hline Altitude (m) & 1600 & 1634 & 2165 & 2177 & 2470 \\
T & 5.4 & 3.1 & 0.5 & 0.4 & -0.9 \\
P & 1317 & 1617 & 1244 & 1238 & 1041 \\
Rd & 116 & 123 & 135 & 128 & 124 \\
HS & 30 & 48 & 86 & 82 & 128 \\
HN & 380 & 537 & 714 & 643 & 768 \\
Sd & 34 & 38 & 62 & 49 & 62 \\
\hline
\end{tabular}

T: temperature $\left({ }^{\circ} \mathrm{C}\right)$; P: precipitation $(\mathrm{mm})$; Rd: rainy days; HS: snow depth $(\mathrm{cm}) ; \mathrm{HN}$ : fresh snow (cm); Sd: snowy days.

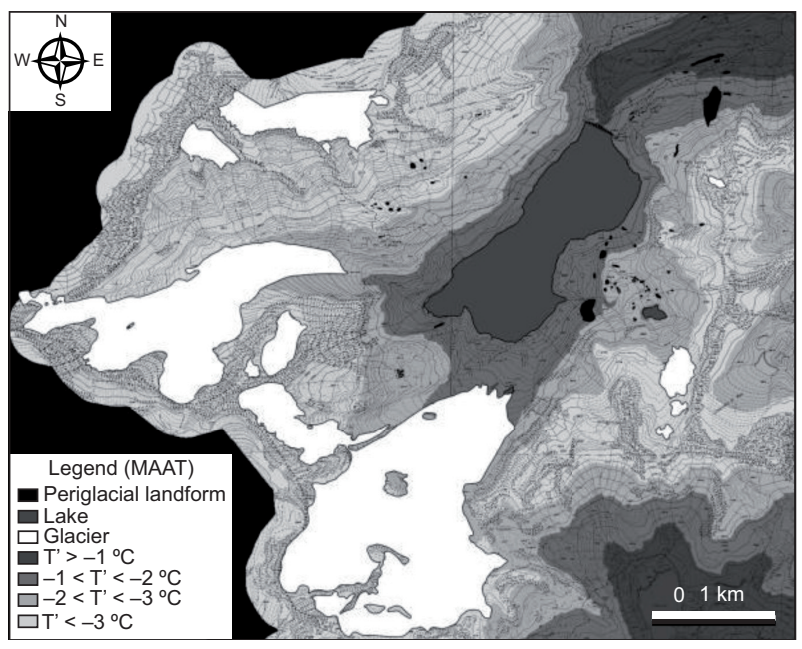

Fig. 5. Mean annual air temperature map.

The average value of the thermal adiabatic gradient is $0.64^{\circ} \mathrm{C} / 100 \mathrm{~m}$; precipitation shows a significant decrease of $-41 \pm 11 \mathrm{~mm} / 100 \mathrm{~m}$; the snow depth has a significant increase of $9 \pm 1 \mathrm{~cm} / 100 \mathrm{~m}$; the fresh snow shows a non-significant increase of $34 \pm 7 \mathrm{~cm} / 100 \mathrm{~m}$.

From these data, a mean annual air temperature map was produced, based on a $5 \mathrm{~m}$ digital terrain model (DTM) of the Piedmont region (Fig. 5). Three temperature thresholds were characterized:

$-1{ }^{\circ} \mathrm{C}$, indicating the lower altitudinal limit of discontinuous permafrost and potential presence of some permafrost indicator landforms (Haeberli, 1985; Haeberli et al., 2010);

$-2{ }^{\circ} \mathrm{C}$, indicating environments in which frost action dominates (French, 2007);

$-3{ }^{\circ} \mathrm{C}$, lower limit of areas affected by the likely presence of large quantities of permafrost (Haeberli et al., 2010).
The MAAT map shows that glaciers are mainly located within the MAAT $<3{ }^{\circ} \mathrm{C}$ class (with the exception of the middle and frontal zones of northern and southern Sabbione glaciers), suggesting a probable presence of suitable conditions for permafrost aggradation within debris deposits and outcropping bedrock surrounding the glaciers. The two rock glaciers in the basin, which are considered as permafrost indicators, are included in the $-2{ }^{\circ} \mathrm{C}<$ MAAT $<-1{ }^{\circ} \mathrm{C}$ condition and their fronts are located at 2475 and 2505 masl.

Periglacial landforms resulting from frost heaving and frost sorting processes, such as non-sorted circles and frost-boils, were found within debris deposits, in particular till. The $90 \%$ of these periglacial landforms in the basin is located at altitudes higher than 2500 masl and in areas with MAAT between -1 and $-2{ }^{\circ} \mathrm{C}$, where debris deposits are predominant.

The frostaction becomes dominantabove 2650 masl, where MAAT is below $-2{ }^{\circ} \mathrm{C}$, while the lower limit of zones characterized by the likely presence of large quantities of permafrost (MAAT $<-3{ }^{\circ} \mathrm{C}$ ) is located above the threshold altitude of 2820 masl.

Finally, to analyze the correlation between climatic parameters and glacial regression, we have considered the cumulative glacier's regression, which permits to avoid incorrect annual data comparison (Guggino Picone and Gramignani, 1966) due to limited missing values in annual glaciological campaigns (e.g., lack of measurements during the period 19841985). We have also compared the annual frontal regression with climatic parameters (temperatures and fresh snow), but the correlation is low; the values are both positive and negative and they show a random distribution. 


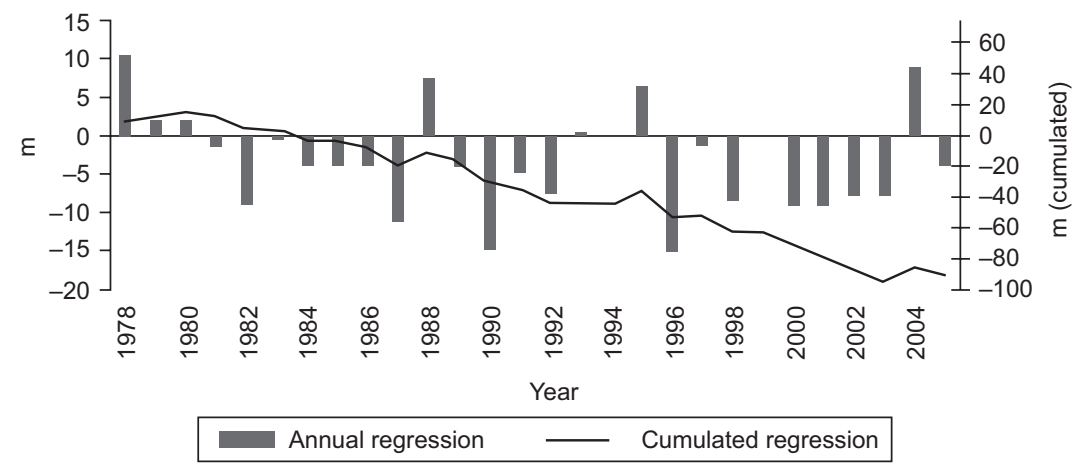

Fig. 6. Northern Sabbione glacier regression.
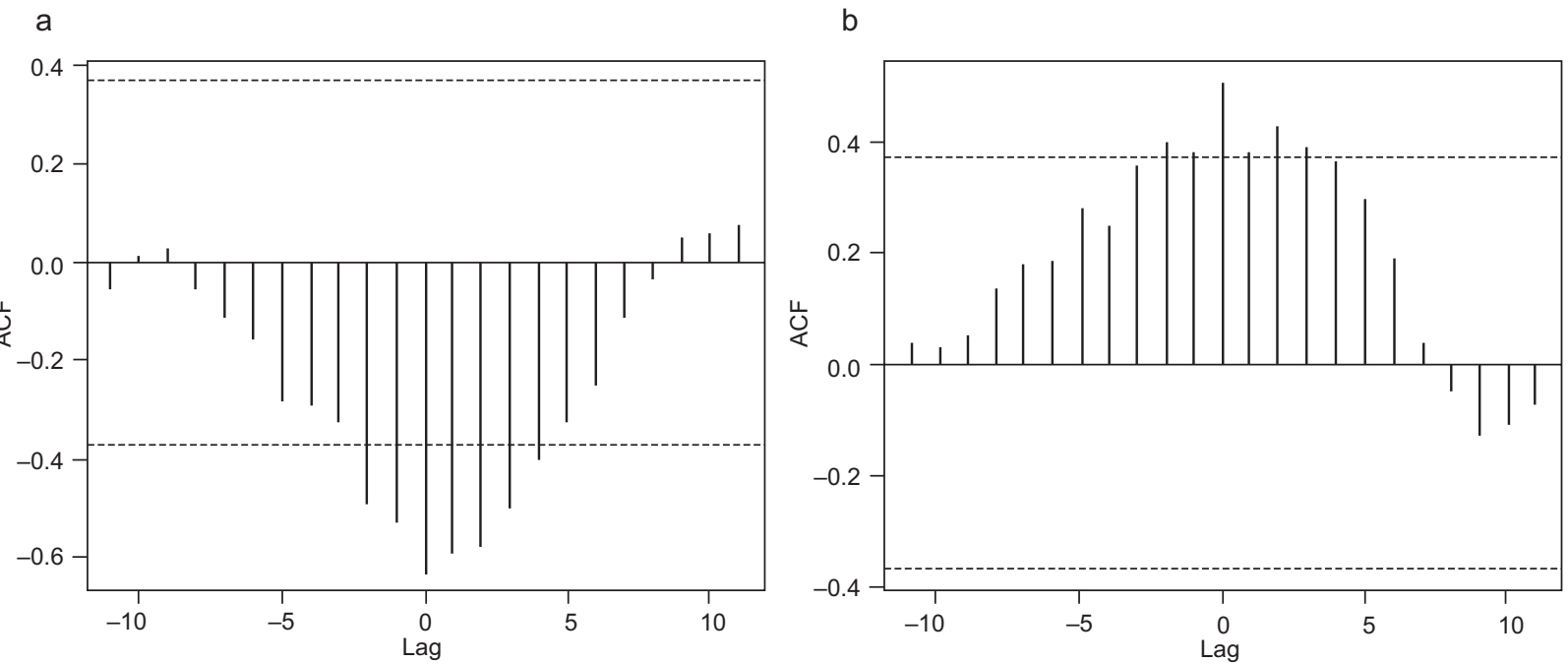

Fig. 7. (a) Correlation between maximum temperatures and glacier cumulated variations. (b) Correlation between fresh snow and glacier cumulated variations. The dotted lines highlight the $95 \%$ significant level. Y-axis represents the cross-correlation values and $\mathrm{X}$-axis the lags, 1 lag $=1$ year.

The analysis of frontal regression of the northern Sabbione glacier between 1978 and 2005 shows that the glacier underwent a cumulative reduction of $-90 \mathrm{~m}$ (Fig. 6). The correlation between glacier variations (retreat) and maximum temperature is negative. The maximum correlation $(-0.628)$ is for lag $=0$ highlighting an immediate response of the glacier with the maximum temperature values (Fig. 7a). Significant values of correlation were estimated also from lag $=1$ to lag $=4$ indicating that high values of Tmax likely lead to the reduction of the glacier during the four following years.

The glacier dynamics appears less influenced by the fresh snow parameter. The correlation is higher than 0.4 (which is a good correlation threshold) only at lag $=0$ (0.506) (Fig. 7b) showing an immediate response of the glacier with the fresh snow influence.

\section{Conclusions}

The Sabbione basin is characterized by the presence of periglacial domain with a mean annual air temperature comprised between -1 and $3{ }^{\circ} \mathrm{C}$ (French, 1996, 2007); in particular, the basin is located in a permafrost environment, according to the definitions proposed by Guglielmin (2004), with MAAT below $0{ }^{\circ} \mathrm{C}$ and rainfall below $2000 \mathrm{~mm} /$ year (André, 2003; Boelhouwers, 2003).

The data derived from the analysis of the long period Sabbione station (located near the glacier) monitoring over time, confirm the ongoing climatic conditions in the Alps. The climatic evolution of the studied area since the end of the LIA has caused a substantial decrease in glacial masses. In particular, the climatic trends of the past 60 years are the main cause of the pronounced glacial decline which is 
originated primarily by ablation augmentation, due to the thermic increase in air temperatures, and secondly by alimentation reduction caused by decrease in snow fresh.

This study, as other studies conducted on several sites of the Ossola Valley, evidences the ongoing climate evolution in the Western Alps. In particular, glaciers show a highly susceptible respond to the effects of summer temperatures and fresh snow, as demonstrated by the present work results about SAI and cross-correlation analyses. Furthermore, the regression of glaciers allows the instauration of cryotic processes in deglaciated areas, with the formation of periglacial landforms.

If the current climatic trends continue in the future, a further and accelerated glacial reduction is expected as function of temperature and solid precipitation influence. Long-term in situ measurements are needed to assess the complex interactions between climate and glaciers in order to better understand the effective ongoing processes and to provide data for reliable projections of future glacier evolution.

At high altitude, the Alps are characterized by the presence of glacial and periglacial environments which are currently susceptible to significant transformations, as shown in this case study; thus, the analysis of the relationships among climate, glacial and periglacial environments is important to understand the future evolution of high alpine landscape under climate change effects.

\section{Acknowledgments}

This research was developed in the framework of the PRIN 2010-11 (funded project of the Italian Ministry for Education and Research) named "Response of morphoclimatic system dynamics to global changes and related geomorphological hazards" (national coordinator, C. Baroni) and the project Nextsnow (national coordinator, V. Levizzani; unit scientific responsible, S. Fratianni).

\section{References}

Acquaotta F., N. Colombo, S. Fratianni, V. Romeo and S. Barbero, 2015. Preliminary results of a comparison study between two independent snow networks in northwestern Italian Alps (Piemonte region). Engineering geology for society and territory, vol. 1, Springer, Switzerland, pp. 113-116.
Acquaotta F. and S. Fratianni, 2013. Analysis on long precipitation series in Piedmont (northwest Italy). American Journal of Climate Change 2, 14-24.

Acquaotta F. and S. Fratianni, 2014. The importance of the quality and reability of the historical time series for the study of climate change. Revista Brasileira de Climatologia 14, 20-38.

Acquaotta F., S. Fratianni and C. Cassardo, 2009. On the continuity and climatic variability of the meteorological stations in Torino, Asti, Vercelli and Oropa. Meteorol. Atmos. Phys. 103, 279-287.

Acquaotta F., S. Fratianni and D. Garzena, 2014. Temperature change in the northwestern Italian Alps from 1961 to 2010. Theor. App. Climatol., doi:10.1007/ s00704-014-1316-7.

André M. F., 2003. Do periglacial landscapes evolve under periglacial conditions? Geomorphology 52, 149-164.

Auer I., R. Böhm, A. Jurkovic, W. Lipa, A. Orlik, R. Potzmann, W. Schoner, M. Ungersbock, C. Matulla, K. Briffa, P. Jones, D. Efthymiadis, M. Brunetti, T. Nanni, M. Maugeri, L. Mercalli, O. Mestre, J. M. Moisselin, M. Begert, G. Muller-Westermeier, V. Kveton, O. Bochnicek, P. Stastny, M. Lapin, S. Szalai, T. Szentimrey, T. Cegnar, M. Dolinar, M. Gajic-Capka, K. Zaninovic, Z. Majstorovic and E. Nieplova, 2007. Historical instrumental climatological surface time series of the Greater Alpine Region 1760-2003. Int. J. Climatol. 27, 17-46.

Barnett T. P., J. C. Adam and D. P. Lettenmaier, 2005. Potential impacts of a warming climate on water availability in snow-dominated regions. Nature $\mathbf{4 3 8}$, 303-309.

Baroni C., A. Carton and R. Seppi, 2004. Distribution and behaviour of rock glaciers in the Adamello-Presanella Massif (Central Alps, Italy). Permafrost Periglac. 15, 243-260.

Barsch D., 1996. Rockglaciers: Indicators for the present and former geoecology in high mountain environments. Springer, Berlin, 331 pp.

Belloni S., G. Diolaiuti, G. Peretti, G. Rossi, C. Smiraglia and N. Tosi, 2001. Un nuovo metodo per la valutazione degli effetti delle condizioni termiche e pluviometriche sulle oscillazioni frontali recenti dei ghiacciai alpini (applicato al Ghiacciaio del Dosegù, Alta Valtellina). Supplemento Geografia Fisica e Dinamica Quaternaria V, 9-17.

Beniston M., 2005. Mountain climates and climatic change: An overview of processes focusing on the European Alps. Pure Appl. Geophys. 162, 1587-1606.

Boelhouwers J., 2003. The maritime subantarctic, a distinct periglacial environment. Geomorphology 52, 39-55. 
Böhm R., I. Auer, M. Brunetti, M. Maugeri, T. Nanni and W. Schöner, 2001. Regional temperature variability in the European Alps: 1760-1998 from homogenized instrumental time series. Int. J. Climatol. 21, 1779-1801.

Brown R. J. E. and T. L. Péwé, 1973. Distribution of permafrost in North America and its relationship to the environment: A review. In: Permafrost, North American contribution to the Second International Conference on Permafrost, Yakustsk, USSR, 13-28 July, 71-100.

Canevarolo, N., D. Testa, S. Fratianni, F. Acquaotta and S. Terzago, 2011. Variabilità climatica e rischio valanghivo in Valle Ossola. Neve e Valanghe 72, 24-33.

Cat Berro D., V. Acordon and G. Di Napoli, G., Eds., 2008. Cambiamenti climatici sulla montagna piemontese. Società Meteorologica Subalpina, Bussoleno, Italia, 142 pp.

Chen C., 1982. Statistical pattern recognition. In: Digital waveform processing and recognition (C. Chen, Ed.), CRC Press, 59-74.

Childers R. K., 1982. Digital spectral analysis. In: Digital waveform processing and recognition (C. Chen, Ed.) CRC Press, 23-59.

Colombo N., S. Fratianni, E. Giaccone and L. Paro., 2013. Relationships among atmosphere-cryosphere-biosphere in a transitional glacial catchment (Sabbione Lake, northwestern Italian Alps). Proceedings of the 20th International Snow Science Workshop, Grenoble-Chamonix Mont-Blanc, 1201-1207.

EEA 2009. Regional climate change and adaptation. The Alps facing the challenge of changing water resources. EEA Report No. 8. European Environment Agency.

Fratianni S., C. Cassardo and R. Cremonini, 2009. Climatic characterization of foehn episodes in Piedmont, Italy. Geogr. Fis. Din. Quat. 32, 15-22.

Fratianni S., S. Terzago, F. Acquaotta, M. Faletto, D. Garzena, M. C. Prola and S. Barbero, 2015. How snow and its physical properties change in a changing climate alpine context? Engineering geology for society and territory, vol. 1, Switzerland, Springer, pp. 57-60.

French H. M., 1996. The periglacial environment. 2nd ed. Harlow, Longman, 341 pp.

French H. M., 2007. The periglacial environment. 3rd ed. Chichester, John Wiley and Sons, 458 pp.

Guggino Picone E. and M. Gramignani, 1966. Sull'analisi “doppia cumulata" per precipitazioni annue. L'Energia Elettrica 9, 521-530.

Guglielmin M., 2004. Observation on permafrost ground thermal regimes from Antarctica and the Italian Alps, and their relevance to global climate change. Global Planet. Change 40, 159-167.

Guglielmin M. and C. Tellini, 1994. Rilevamento del permafrost con il metodo BTS (bottom temperature of the winter snow cover) nell'Alta Valtellina (Sondrio, Italia). Geografia Fisica e Dinamica Quaternaria 17, 47-54

Haeberli W., 1973. Die Basis-Temperatur der winterlichen Schneedecke als moglicher Indikator für die Verbreitung von Permafrost in den Alpen. Zeitschrift für Gletscherkunde und Glazialgeologie 9, 221-227.

Haeberli W., 1985. Creep of mountain permafrost. Internal structure and flow of alpine rock glaciers. E.T.H., Zurich, $142 \mathrm{pp}$.

Haeberli W., J. Noetzli, L. Arenson, R. Delaloye, I. Gartner-Roer, S. Gruber, K. Isaksen, C. Kneisel, M. Krautblatter and M. Phillips, 2010. Mountain permafrost: Development and challenges of a young research field. J. Glaciol. 56, 1043-1058.

Hereford R., R. H. Webb and S. Graham, 2002. Precipitation history of the Colorado Plateau region, 19002000. United States Geological Survey, Fact Sheet 119-02, 4 pp.

IPCC, 2007. Climate change 2007. The physical science basis. Contribution of Working Group I to the Fourth Assessment Report of the Intergovernmental Panel on Climate Change (S. Solomon, D. Qin, M. Manning, Z. Chen, M. Marquis, K. B. Averyt, M. Tignor, H. L. Miller, Eds). Cambridge University Press, Cambridge, United Kingdom and New York, 996 pp.

Leonelli G., M. Pelfini, R. D’Arrigo, W. Haeberli and P. Cherubini, 2011. Non-stationary responses of tree-ring chronologie and glacier mass balance to climate in the European Alps. Arctic, Antarctic and Alpine Research 43, 56-65.

Kearey P. and M. Brooks, 1991. An introduction to geophysical exploration. Blackwell Scientific Publication, Oxford, $254 \mathrm{pp}$.

Klein Tank A. M. G., Zwiers F. W. and Zhang X., 2009. Guidelines on analysis of extremes in a changing climate in support of informed decisions for adaptation. Climate Data and Monitoring WCDMP-No. 72. Geneva, World Meteorological Organization.

Mazza A., 1993. Evoluzione del Ghiacciaio del Hohsand (Val Formazza, Alpi Lepontine). Nimbus 3, 26-32.

Mazza A., 2007. Il grande Ghiacciaio dell'Hohsand: sua evoluzione dal 1800 ad oggi. Interpretazione nel quadro della meccanica dei ghiacciai. Terra glaciālis. Annali di cultura glaciologica 10, 107-119. 
Mazza A. and L. Mercalli, 1992. Il Ghiacciaio Meridionale dell'Hohsand (Alta Val Formazza): un secolo di evoluzione climatica e i rapporti con la produzione idroelettrica. Oscellana 22, 30-44.

Nigrelli G. and M. Collimedaglia, 2012. Reconstruction and analysis of two long-term precipitation time series: Alpe Devero and Domodossola (Italian Western Alps). Theor. Appl. Climatol. 109, 397-405.

Peterson T. C., D. R. Easterling, T. R. Karl, P. Groisman, N. Nicholls, N. Plummer, S. Torok, I. Auer, R. Boehm, D. Gullett, L. Vincent, R. Heino, H. Tuomenvirta, O. Mestre, T. Szentimrey, J. Salinger, E. Førland, I. Hanssen-Bauer, H. Alexandersson, P. Jones and D. Parker, 1998. Homogeneity adjustments of in situ atmospheric climate data: A review. Int. J. of Climatol. 18, 1493-1517.

Péwé T. L., 1969. The periglacial environment. In: The periglacial environment (T. L. Péwé, Ed.) McGill-Queen's University Press, Montreal, 1-9.

Senese A., G. Diolaiuti, C. Mihalcea and C. Smiraglia, 2012. Energy and mass balance of Forni Glacier (Stelvio National Park, Italian Alps) from a four-year meteorological data record. Arctic, Antarctic and Alpine Research 44, 122-134.

Sneyers R., 1990. On statistical analysis of series of observations. Technical note $N^{\circ} 143$, World Meteorological Organization, Geneva.

Sneyers R., 1992. Use and misuse of statistical methods for the detection of climate change. In: 12th Conference on Probability and Statistics in the Atmospheric Sciences, Toronto, Boston, American Meteorological Society.

Telford W., L. Geldart and R. Sheriff, 1992. Applied Geophysics. Cambridge University Press, Cambridge, $860 \mathrm{pp}$.
Terzago S., C. Cassardo, R. Cremonini and S. Fratianni, 2010. Snow precipitation and snow cover climatic variability for the period 1971-2009 in the southewestern Italian Alps: The 2008-2009 snow season case study. Water 2, 773-787.

Terzago S., R. Cremonini, C. Cassardo and S. Fratianni, 2012. Analysis of snow precipitation during the period 2000-09 and evaluation of a snow cover algorithm in SW Italian Alps. Geografia Fisica e Dinamica Quaternaria 35, 91-99.

Terzago S., S. Fratianni and R. Cremonini, 2013. Winter precipitation in western Italian Alps (1926-2010): Trends and connections with the North Atlantic/Arctic Oscillation. Meteorol. Atmos. Phys. 119, 125-136.

Tricart J., 1968. Periglacial landscapes. In: Encyclopaedia of geomorphology (R. W. Fairbridge, Ed.). Reinhold, New York, pp. 829-833.

Venema V. K. C., O. Mestre, E. Aguilar, I. Auer, J. A. Guijarro, P. Domonkos, G. Vertacnik, T. Szentimrey, P. Stèpànek, P. Zahradnicek, J. Viarre, G. Müller-Westermeier, M. Lakatos, C. N. Williams, M. J. Menne, R. Lindau, D. Rasol, E. Rustemeier, K. Kolokythas, T. Marinova, L. Andresen, F. Acquaotta, S. Fratianni, S. Cheval, M. Klancar, M. Brunetti, C. Gruber, M. Prohom Duran, T. Likso, P. Esteban and T. Brandsma, 2012. Benchmarking homogenization algorithms for monthly data. Clim. Past. 8, 89-115.

Wijngaard J. B., A. M. G. Klein Tank and P. Können, 2003. Homogeneity of 20th century European daily temperature and precipitation series. Int. J. Climatol. 23, 679-692.

Zhang X. and F. Yang, 2007. RclimDex (1.0). User manual. Climate Research Branch, Environment Canada, Ontario. 